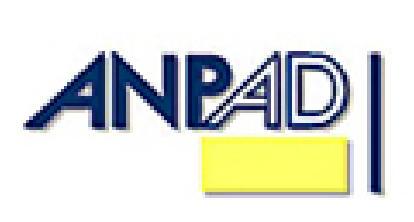
Available online at
http://www.anpad.org.br/bar
BAR, Rio de Janeiro, v. 12, n. 4, art. 4, pp. 384-402, Oct./Dec. 2015
http://dx.doi.org/10.1590/1807-7692bar2015150041
(c) $B Y$

\title{
Effects of Path Dependence on Capabilities in Captive Global Value Chains
}

Silvio Luis de Vasconcellos Universidade do Vale do Rio dos Sinos - UNISINOS/PPGAdm

Ivan Lapuente Garrido Universidade do Vale do Rio dos Sinos - UNISINOS/PPGAdm

Luciana Marques Vieira Universidade do Vale do Rio dos Sinos - UNISINOS/PPGAdm

Luis Carlos Schneider Universidade do Vale do Rio dos Sinos - UNISINOS/PPGAdm

Received 7 August 2015; received in revised form 16 November 2015; accepted 17 November 2015; published online 15 December 2015.

Editor's note. Marcos André Mendes Primo served as Action Editor for this article. 


\begin{abstract}
Global Value Chains (GVC) and their participants are dynamic. Events can provoke distinct strategic responses from different firms, even when they are part of a GVC. We investigated how both organizational and supplychain path dependence can influence the capabilities that a firm needs to achieve a higher value-added position in a GVC. We have integrated three branches of theory, covering Global Value Chains, Organizational Capabilities, and Path dependence. We conducted a case study of a large Brazilian shoe firm, analyzing its relationships with buyers in GVCs. We found that path-dependent elements had locked-in the firm, preventing ascension to higher added value positions and keeping the organization in captive global value chain, even when it moved into new markets. Additionally, we propose a theoretical model that should prove fruitful in future research in other sectors and countries.
\end{abstract}

Key words: global value chain; capabilities; path dependence; case study. 


\section{Introduction}

Value chain manufacturing is far from being a recent phenomenon. However, the process has clearly accelerated over the last few decades. During the same period in which managers were realizing that fragmentation of production activities could produce higher returns, international production adopted the same logic to take advantage of the resources available in different parts of the globe. Over time, supply chains evolved not only because of lower transaction costs, but also as a result of economies of scale and reduced production costs enabled by changing industry standards. At the micro level, development of capabilities among suppliers contributes to this evolution (Gereffi, Humphrey, \& Sturgeon, 2005). Furthermore, these capabilities are marked by the legacy of historic decisions that will continue to affect future decisions in a form of path-dependency (Arthur, 1989; Mahoney, 2000).

Gereffi, Humphrey and Sturgeon (2005) illustrated this dynamic phenomenon using the bicycle industry as one of his examples, as used by Galvin and Morkel previously (2001). Initially (in the 1890s), bicycle manufacturing was vertically integrated, but later the production process became fragmented globally. By 2000, manufacturing was distributed in several places, in several stages, and the products sold under well-known brands such as Shimano (Gereffi et al., 2005). The speed at which change in manufacturing happens is related to the characteristics of the industry, mainly according to the type of governance an industry tends to employ (Gereffi, 1994). As such, one aspect that is relevant to understanding configuration and coordination of supply chains is to identify the mode of governance and how it develops over time.

Although we can consider some isolated cases of vertical integration in the early 21 st century, a radical shift gained intensity during the last quarter of the 20th century, mostly in horizontal production, by outsourcing and offshoring. Jarillo (1993) highlighted three types of organizational system: vertical integration, outsourcing networks and cooperation strategies. The vertical production model that had prevailed throughout the majority of the $20^{\text {th }}$ century exhibited vulnerabilities in comparison to forms of production that are more efficient in terms of transaction costs (Williamson, 1975) and control over the whole process (Gereffi et al., 2005).

The impact of information technology, improved transport systems and innovation demanded fast responses from firms. As Jarillo (1993) mentioned, one alternative model that emerged before the collapse of the vertical system can be illustrated by the outsourcing methods of Ford and Nike. Over the last three decades, market integration and geographical dispersion of production have led to the emergence of global chains (Feenstra, 1998). Emerging countries play an important role in this process, both by performing some value chain activities and as expanding markets for consumer goods.

From a theoretical perspective, certain observations have been helpful for explaining how global chains work globally. Gereffi (1994) mentioned two main types of governance of global chains: producer-driven or buyer-driven. In the first case, producer-driven chains are coordinated by large companies, usually transnational, that control the production system both upstream and downstream. These types of chain are more commonly found in technology-intensive sectors, such as the automotive, computing, aerospace, and electronics industries. In the second case, buyer-driven chains exist in industries in which there are large retailers, brand owners and global trading companies. These chains take on a central role in outsourcing the production of commodities, usually in less developed countries. These markets include consumer goods such as garments, shoes, toys and household items, in which production is controlled by companies on the demand side, rather than by the suppliers (Bair, 2009; Gereffi, 1994).

However, while the concept of global chain, being both configuration producer-driven or buyerdriven, has advanced understanding of the governance of supply chains, recent increases in the complexity of transactions demanded further explanation. For instance, changes in institutional environments and economic growth in developing and emerging countries have provided a dynamic perspective on how supply chains are configured to add value (Claessens \& Yurtoglu, 2013; Paiva \& Vieira, 2011; Young, Peng, Ahlstrom, Bruton, \& Jiang, 2008). Gereffi et al. (2005) noted three main 
dimensions that play important roles in the GVC dynamic: the complexity of transactions, the ability to codify transactions, and the capabilities of the supply base. Based on this, Gereffi et al. (2005) postulated five types of global chain governance ranging from hierarchy, through captive, relational and modular to market.

Several factors, including history, institutions, social and geographical context, and pathdependence, influence explanations of how firms or groups of firms connect to each other globally (Gereffi et al., 2005). Indeed, while globalization has provided opportunities for companies to access international markets, it has also threatened the survival of some sectors and firms in certain countries (Paiva \& Vieira, 2011).

In this paper, we explore one specific variable that plays a role in the supply chain dynamics: the capability in the supply-base and, consequently, this is an intra-firm analysis. More specifically, we describe a captive global value chain (as defined by Gereffi et al., 2005) from an organizational perspective and highlight path dependencies that influence strategic decisions. According to Gereffi et al. (2005), in some developing countries, growth of industrial capabilities is redefining the type of supply chain governance. Core capabilities, such as focus on innovation, product strategy, and marketing, are adding value for specific agents within a supply chain and, consequently, changing the power relations. The use of capabilities within a supply chain relates to many factors, including the history of the firm and the history of the supply chain itself, which may or may not be manifestations of path dependencies. Furthermore, the effects of path dependence vary, and can speed up, slow down or even halt the construction of capabilities that would better position the firm (Sydow, Schreyögg, \& Koch, 2009).

In this paper, we aim to understand how path dependence influences the organizational capabilities of a firm that is part of a captive global chain during a period in which the firm is attempting to attain higher added value positions. We formulated the following research questions: How might path dependence influence the development of the capabilities of an organization within a supply chain? How might path dependence result in lock-in that would prevent movement to higher levels in the governance hierarchy of a captive value chain?

In order to attempt to answer this question, we conducted a case study of a shoe manufacturer in Brazil. We chose the footwear industry because it is part of a globalized supply chain and it is also an industry in which players are accustomed to migrate in search of resources (Costa \& Passos, 2004; Rabellotti \& Schmitz, 1999; Schmitz, 2006). Therefore, it provides examples of the types of dynamic changes that constantly challenge managers when developing strategies for adding value to their products or repositioning their firms within GVCs. Moreover, the Brazilian shoe industry has been changing its organizational strategies with the objective of becoming a global player (Paiva \& Vieira, 2011). Although we carry out the GVC and supply chain as an embedded context that is related to events in the trajectory, the analysis of capabilities is at the organizational level (focal firm).

This paper is organized in six sections including this Introduction. The next section presents an overview of literature covering the development and evolution of theory on GVC and organizational capabilities. We have included a sub-section on path dependence in response to a recommendation made by Gereffi et al. (2005) that supply chain reconfiguration should be analyzed and also because of certain observations made during the case study interviews. In the section three we present the research methods employed and in the section four we discuss the case studied, describing both the Brazilian shoe industry as a whole and the specific case investigated. We then analyze the empirical data in the light of the theoretical framework and end by drawing our final conclusions. 


\section{Theoretical Overview}

The theoretical framework that supports this paper is founded in three areas of knowledge. We begin by presenting the background to Supply Chain studies, starting with producer-driven versus buyerdriven configurations (Gereffi, 1994) and supplemented with the typology of GVC governance proposed by Gereffi et al. (2005) and further explored by Paiva and Vieira (2011). Gereffi et al. (2005) considered capabilities to be a specific dimension that can help to explain how supply chains and firms can improve their positions; we cover capabilities in two subsections, discussing organizational capabilities and supply chain capabilities separately. Finally, since history influences both resources and capabilities (Penrose, 1959), we review path-dependence studies, focusing on organizational path dependence and supply chain path dependence.

\section{Global commodity chains}

Global Commodity Chains (GCCs) are systems that establish and coordinate standards of international production and trade, linking firms' economic activities to inter-organizational networks that allow them to develop, to manufacture, and to distribute their products (Gereffi, 1994). Initially, Gereffi (1994) identified two distinct types of governance structures in commodity chains: producerdriven and the buyer-driven configurations.

\section{Producer-driven $x$ buyer-driven}

The manufacturing of certain goods tends to be carried out in several countries, with each one performing the activities in which it has specific (comparative) advantages. This is the situation for manufacturers of footwear and clothing and also with relation to products such as cars and computers (Gereffi, 1989; Gereffi \& Korzeniewicz, 1989). According to Gereffi (1994), these chains are the result of industrial globalization and the revolutions in communications technology and transport, which have allowed large manufacturers and retailers to establish networks for production and trade.

Gereffi (1994) identified four dimensions of commodity chains. The first one is the structure of input and output chains, in which groups of products are integrated to add value; the second one is the geographical dispersion and concentration of production and/or trade networks, themselves composed of different types and sizes; dimension three is the governance structure, which involves the relations of power and authority established between players; and the fourth dimension is the institutional context, which covers the rules governing the relations between firms and the way that chains operate.

\section{Global value-chains}

Although the dimensions described thus far have helped to clarify governance of commodity chains, Gereffi et al. (2005) proposed five distinct dimensions (market-based, modular, relational, captive and hierarchy, which are detailed below) explaining how the governance of global value chains changes as time goes by, adding a dynamic understanding of a supply chain. Bair (2009) describes how the GCC framework evolved into the wider GVC perspective. A value chain describes the full range of activities required to bring a product or service from its conception to delivery to the final consumer, and later disposal, involving all of the different stages of production (Kaplinsky \& Morris, 2001). The vertical disintegration of production in transnational companies, in response to global economic changes, reflects these large companies' change of focus, turning to activities with higher added value and concentrating on developing their core competencies (Gereffi et al., 2005).

The governance structure of the GVC is an essential part of coordination and analysis of transnational production systems (Gereffi, 1994; Gereffi \& Lee, 2012). By analyzing governance structure, it is possible to understand how corporate power can shape the distribution of profits and risks 
in an industry, and how the agents involved exercise such power through their activities (Gereffi \& Lee, 2012).

Gereffi et al. (2005) proposed a typology of value-chain governance that combines relational aspects with the transaction costs perspective and is an updated and expanded version of the earlier approach by Gereffi (1994) based on the distinction between producer-driven and buyer-driven configurations. The newer description has two extreme typologies, market-based and hierarchy, between which three variants are identified: modular, relational, and captive. The term market-based refers to conventional relations governed by costs. Such systems can persist for a long time and the costs of switching to new partners are low. In Modular value chains, suppliers follow buyers' specifications but assume control over turnkey services and keep relevant competencies in their own domain. In relational value chains, there are complex relations between buyers and sellers. Geographical proximity, as well reputation and trust provide the benefit of equilibrium in such systems. In captive value chains, there are networks in which small suppliers are dependent on much larger buyers, which tend to monitor and control the entire network. Finally, in hierarchical value chains, there is vertical integration in a subordinated relationship between headquarters and subsidiaries, or affiliates (Gereffi et $a l ., 2005)$.

Each of these types of governance involves power relations. In a recently-published study, Paiva and Vieira (2011) investigated the role of capabilities in the power relations in the footwear value chain. Capabilities play important roles in such power relations, since players strive to keep capabilities under their own control and, consequently, to obtain and/or maintain better positions within the value-chain. When suppliers take on more relevant roles in a GVC they are trying to move from a global buyer chain to a high added value chain. This transition involves changes to governance to allow them to adopt an active leadership position in the chain and also to have more control over value chain activities, especially those related to high value activities (Paiva \& Vieira, 2011).

According to findings reported by Paiva and Vieira (2011), in the footwear value chain, increasing control of activities is related to the capabilities needed to adopt higher-added value strategies. In GVCs, there are a number of specific differences between higher-added value strategies and buyer-driven strategies. In the higher-added value scenario: (a) producers govern the chain; (b) there is a long-term relationship and integration with buyers; (c) producers design their own products; (d) there is flexibility in relation to sales and production volumes; (e) producers sell directly and govern distribution; (f) producers have agents representing them in target markets; $(\mathrm{g})$ producers focus on small and medium retailers; (h) their products are in conformity with clients' expectations of high quality; (i) producers try to increase verticalization to reach their end consumers; and (j) prices are higher than in buyer-driven scenarios (Paiva \& Vieira, 2011). The move to higher-added value chains therefore involves development of both strategy and capabilities. In this paper, we explore an example of the type of governance that exhibits the greatest imbalance, as conceptualized by Gereffi et al. (2005), which is the type found in captive value-chains.

\section{Capabilities}

According to Grant (1991), capabilities are the primary constants upon which the firm can establish its identity and frame its strategy, and they are the primary sources of the firm's profitability. These different labels refer to specific capabilities that the firm creates and uses strategically to create or add value. Organizational capabilities are firm's capabilities for establishing internal structures and processes that influence its members to create firm-specific competencies and then enable the firm to adapt to changes in customer-specific needs (Ulrich \& Lake, 1990). Teece, Pisano and Shuen (1997) have discussed strategic organizational capabilities. Strategic organizational capabilities involve the mobilization of resources to generate competitive advantages. For Teece et al. (1997), the term capability serves to emphasize the central role of strategic management in adapting, integrating and reconfiguring internal and external organizational skills, resources and functional competencies, cooperating to address the changes that the environment imposes. However, Gereffi et al. $(2005$, p. 81$)$ pointed out that "In practice, even the most vertically integrated firms rarely internalize all the 
technological and management capabilities that are required to bring a product or service to market". Therefore, organizational capabilities reflect a firm's relational abilities to defend positions, respond to the environment and conciliate its own organizational resources to the organizational abilities of partners, suppliers and clients in a relational perspective, which we shall discuss further in the next subsection, covering the role of capabilities in supply chains.

In this paper, we extend the capabilities concept to a supply chain context, where the inter-firm relationship enables to develop and explore capabilities to leverage competitive advantage for the whole supply chain operation. Supply chain capabilities are usually understood through an operational perspective such as trade-off of competitive priorities (Hayes \& Wheelwright, 1984; Morash, 2000) that lead to superior performance (Kim, 2006). This is relevant to this study, as the company needs to possess operations capabilities (price, volume, flexibility, quality and speed to deliver) or/and marketing capabilities (design, branding, relationship management, distribution channels, among others) according to the features of the GVC that it is inserted.

Gereffi et al. (2005) proposed a distinguished perspective, including the dimension of the supplier's capability to characterize the type of governance in a dyadic relationship. In this typology, as higher is the capability of the supplier to learn new techniques or to innovate, the more balanced is the relationship with the buyer. In this paper, the use of capability is aligned to Paiva and Vieira (2011), where the focal firm must have capabilities to develop value chains activities beyond those related to operational functions. These authors suggest that the focal company in order to move to a higher added value position in the chain has to possess capabilities that are not just operational, but also marketoriented, such as design, relationship management, among others.

The choice between make or buy is not only an issue of transaction costs (Williamson, 1992) but it also involves the organizational ability to internally perform certain tasks. This decision may be subject to skills development within the firm (Penrose, 1959) or may be dependent on the complementary expertise of other companies, allowing the firm to focus on its core competencies (Prahalad \& Hamel, 1990).

A supply base is part of a supply network actively managed by a purchasing firm (focal firm), which manages the suppliers' supply base through agreements and the purchase of parts, materials and services (Choi \& Krause, 2006). Each firm that belongs to a supply base develops techniques to respond to the focal firm's capabilities in a dyadic relationship between buyer and supplier.

In a supply chain, capabilities are dispersed across diverse firms and can be moved between them as time goes by. The capabilities of current and potential suppliers depend on the relationships between suppliers and the requirements of the transaction (Gereffi et al., 2005). Supplier capabilities are influenced by the complexity of information that flows between firms and how information can be codified (Gereffi et al., 2005). To achieve a position of greater power within the supply chain, those selling to other supply chain members must increase their competencies. In a captive chain, foreign firms take responsibility for controlling and monitoring their suppliers' suppliers, taking care of designing and sampling and monitoring quality, interfering in negotiations between antecedent suppliers and guaranteeing on-time delivery (Gereffi et al., 2005).

As was pointed out by Penrose (1959), managers are responsible for changing organizational resources and capabilities. Strategic decisions may contribute to a transition from a captive value-chain governance model to a higher added value position (Paiva \& Vieira, 2011). However, sometimes the existing theoretical frameworks are unable to explain how decision-making takes place (Mahoney, 2000). The concept of GVC path dependence could help us to clarify such situations by acknowledging that initial conditions that are characteristics of the chain influence decision-making at critical conjectures. 


\section{Path dependence}

Path dependence is the reason the QWERTY keyboards are dominant to date, even in smartphones. David (1985) used the QWERTY sequence to exemplify path dependence, since the result of an ancient strategy for selling typewriters still influences high technology devices today. Putting certain keys on the same row allowed salespeople to demonstrate the efficiency of typing the word typewriter without locking up the mechanism, which had been a common problem with the first typewriters sold between 1870 and 1880. Although this was not the ideal solution, factors such as habits (linked to users' learning curves) and the costs of change prevented other key sequences from superseding QWERTY (David, 1985). In economics, Arthur (1989) noted that certain small events could modify the trajectories of investments in stock options. Strategic studies have included history as a relevant influence on how decisions are made (Barney, 1991; Peng, 2002; Teece, Pisano, \& Shuen, 1997). However, it is far from clear why, in certain circumstances, the path that would lead to the most appropriate destination is rejected or ignored (Vasconcellos, Calixto, Garrido, \& Souza, 2012).

In organizational terms, path dependence refers to observing the past to understand how standards become routine. Path dependence also deals with observing how standards have been changed by certain events, although the events of history that preceded them cannot explain some decisions. The genesis of path dependence is institutional and originates in a given option chosen at some point in the history of a firm at a critical juncture, when the manager decides to stop and question after the previous counterfactual analysis, in a situation that is imposed as a contingency, and takes a decision to deal with it (Mahoney, 2000), as illustrated in Figure 1.

A

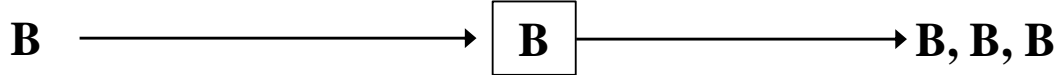

C

\begin{tabular}{|c|c|c|}
\hline $\begin{array}{c}\text { Time } 1 \\
\text { (Initial Conditions) }\end{array}$ & $\begin{array}{c}\text { Time } 2 \\
\text { (Critical Juncture) }\end{array}$ & $\begin{array}{c}\text { Time 3+ } \\
\text { (Self-reinforcement) }\end{array}$ \\
\hline $\begin{array}{l}\text { Multiple options }(\mathrm{A}, \mathrm{B}, \mathrm{C}) \text { are } \\
\text { available for selection. Theory is } \\
\text { unable to predict or explain the } \\
\text { option that will be adopted. }\end{array}$ & $\begin{array}{l}\text { Option B is initially favored } \\
\text { over competing options. This } \\
\text { is a contingent event. }\end{array}$ & $\begin{array}{l}\text { Option B capitalizes on } \\
\text { initial advantage and is } \\
\text { stably reproduced over } \\
\text { time. }\end{array}$ \\
\hline
\end{tabular}

Figure 1. Illustration of Contingency in a Self-reinforcing Sequence

Source: Mahoney, J. (2000). Path dependence in historical sociology (p. 514). Theory and Society, 29(4), 507-548.

In Figure 1, at Time 1 managers have different options. No theory can predict which will be adopted. At a critical point (Time 2), one of these options will be favored. This advantage will be reflected in future decisions (Time 3+), sometimes accelerating the process of decision-making and other times provoking lock-in of past decisions. In international business, path dependence reflects the consequences of decision and also reflects learning and commitment (organizational issues), entry mode choices (economic influences) and institutional power (institutions) (Vasconcellos et al., 2012). In this paper, we focus on organizational path dependence and path dependence in GVC. In our understanding, path dependence in supply chains reflects economic and institutional influences on organizational capabilities. 


\section{Organizational path dependence}

"Where a firm can go is a function of its current position and the paths ahead" (Teece et al., 1997, p. 522). The position of the firm reflects the way that managers filter the past through a lens located in the present, recreating the firm's history in its own terms (Booth, 2003). Additionally, the arsenal of capabilities a firm has built on its history reflects a historical sequence of decisions (Nelson \& Winter, 1982), which influences decisions in the present and, consequently, in the future.

The historical heritage of the firm is one of the driving factors that contribute to competitors' inability to imitate a competitive advantage. A firm's ability to obtain a resource depends on the unique conditions of its past (Barney, 1991). The historical trajectory of the firm is a source of unity, through the development of skills, capabilities and inimitability (Barney, 1995). Investments in the past, learning and the repertoire of routines that dominate the firm contribute to building elements of its future, enabling the firm to acquire a more accurate perception of its environment.

Path dependence does not only enable access to scarce resources, thereby differentiating the firm from its competitors, but path dependence can also inhibit reconfiguration of resources (Jarzabkowski, 2002). The critical juncture becomes loaded with established habits that favor organizational inertia, and resources can erode quickly. Path dependence can therefore be responsible for either accelerating or for moderating changes in organizational capabilities.

Sydow, Schreyögg and Koch (2009) defined organizational path dependence as a process that is triggered by a critical event leading to a critical moment. Influenced by decisions made in other critical moments, path dependence ensures a regime that governs self-reinforcing feedback as a specific pattern of social practices, which gain more and more dominance over the alternatives. Finally, path dependence may cause organizational lock-in, restricting future decision-making (Sydow et al., 2009). Sydow et al. (2009) identified three levels for investigation, specifically, the individual level, the network level and the field level. The next subsection, in which we discuss path-dependence in supply chains is concerned with the field level.

\section{Path dependence in supply chains}

Large companies are usually members of supply chains. Given the complexity involved and the effects of path dependence, there are strong constraints on managerial choice in shaping the technology strategies of large firms (Patel \& Pavitt, 1997). As a result, large firms' "competencies in technology are not enough" and they "must also be competent to coordinate technological change and improvement in their supply chains, and to evaluate and exploit emerging technological opportunities" (Patel \& Pavitt, 1997, p. 154). Since their capabilities are limited and dependent on other companies, large firms are subject to limitations to the extent to which they are able to achieve technological accumulation.

While being part of a supply chain provokes a lower degree of technological accumulation, such a position also provides access to inter-firm relationships, which are usually complex and long-term relationships (Håkansson \& Ford, 2002). As such, relationships enable companies to manage their increasing technological dependence on others. According to Håkansson and Ford (2002), the development of any relationship between companies is dependent on previous experience in other relationships, on the current relationship and on both companies' expectations of their future interactions.

All companies have their own histories. When more than one company is engaged in a supply chain relationship, there is mutual path dependence, generally when one of them owns a specific technology or asset. This may cause lock-ins throughout the entire supply chain (Holweg \& Pil, 2008). Therefore, the governance of a GVC is subject to influences from several different organizational histories. Since firms are linked, history is a variable that "plays a relevant role in determining patterns of the value-chain governance ... Clearly, history, institutions, geographic and social contexts, the 
evolving rules of the game, and path dependence matter; and many factors will influence how firms and groups of firms are linked in the global economy" (Gereffi et al., 2005, p. 82).

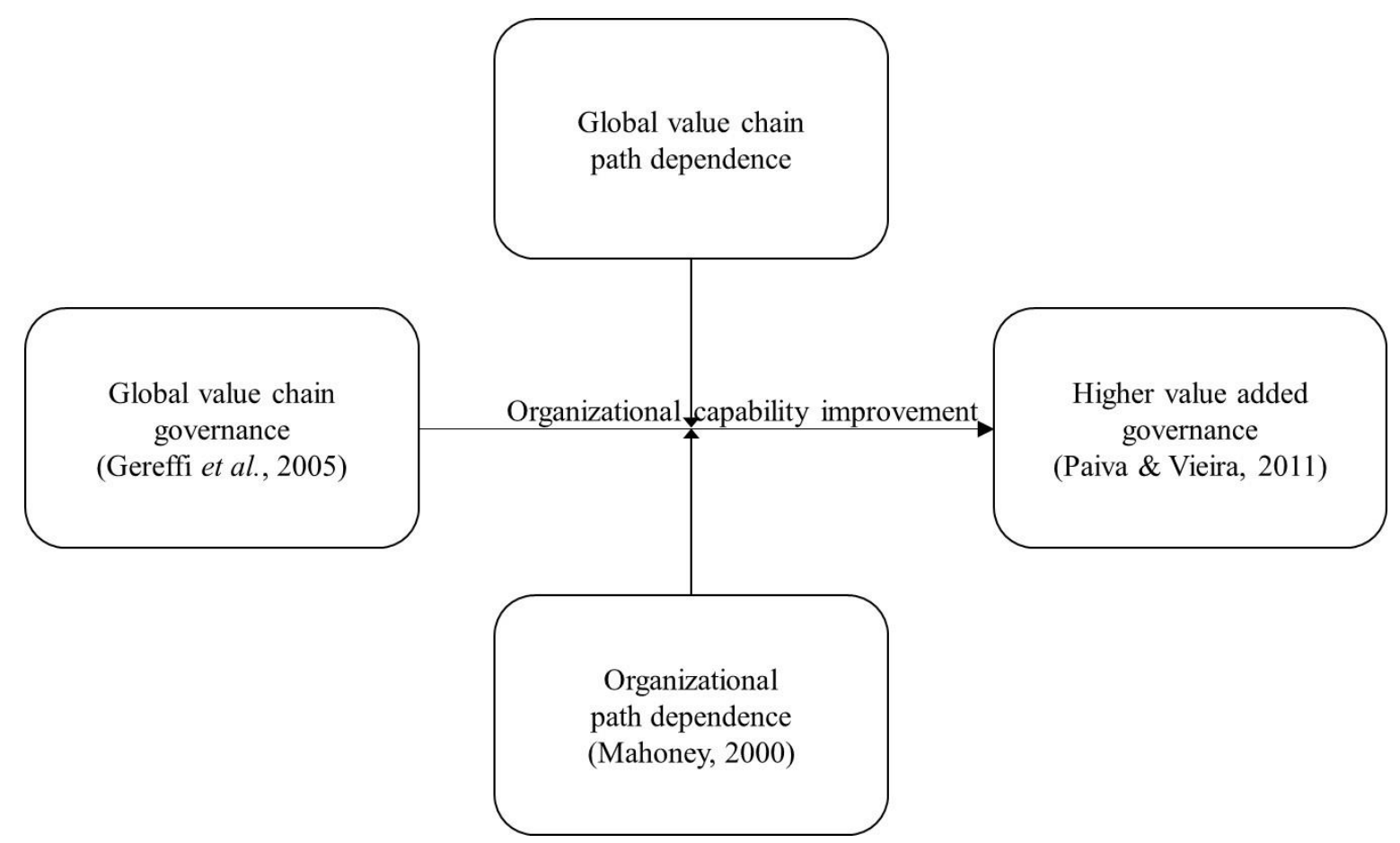

Figure 2. Capability Improvement in GVC from a Path Dependence Perspective

In Figure 2, we present the a priori framework supporting our research. As we have discussed in this theoretical overview, possessing or developing capabilities may help firms move up the supply chain power hierarchy. Nevertheless, the main assumption of our framework is that the Global Value Chain path dependence influences the Governance (any of the five types according to Gereffi et al., 2005) and lead to the development of organizational capabilities for companies intending to move to higher added value chain. The GVC path dependence also influences the organizational path dependence. In sum, this means that companies take decisions according to the events and kind of GVC that they are engaged. The model can be applied to any kind of GVC governance but in this study it will support a captive chain case study. The captive governance is when supplier has low capabilities and less bargain power facing buyers therefore we consider it the most illustrative for an exploratory case study.

\section{Method}

We have divided this paper into two parts: a theoretical-exploratory element and a conclusivedescriptive analysis of empirical data that we collected in the field. First, we sought to delineate the problem under investigation, synthesizing literature from the relevant theoretical fields, in order to construct a theoretical framework for the investigation.

We used the case study method. According to Eisenhardt (1989), case studies are recommended when the focus lies in understanding the dynamics of unique situations that can be investigated through single cases or at different levels. We chose a case in this specific industry for a number of different reasons. The footwear industry has been studied worldwide as an example of a sector with buyer-driven supply chains (Gereffi, 1999; Navas-Alemán, 2011; Paiva \& Vieira, 2011; Schmitz, 2006). The target firm is located in an emerging country, Brazil, and, more precisely, in the Sinos Valley region of Brazil's Southernmost state, Rio Grande do Sul. Traditionally, Brazilian manufacturers of shoes for export were coordinated by transnational companies (from the US and the EU) that purchased their production and 
monitored the production process through to shipping of the product ready for export, as described in Schmitz and Knorringa (2000) and Rabellotti and Schmitz (1999).

We studied an exporting shoe company from Sinos Valley, Brazil. The Sinos Valley is home to the largest footwear manufacturing cluster in Brazil and one of the most recognized in the world (Costa \& Passos, 2004; Gereffi, 1999; Navas-Alemán, 2011; Rabellotti \& Schmitz, 1999; Schmitz, 2006). Our criterion for choosing this firm was its long-term presence in the foreign market. ShoeBR (fictitious name) had been exporting since 1971, which is when Brazil first began to figure as an international player in GVC. ShoeBR has six plants employing 1,500 people and producing 10,000 pairs of women's shoes bearing client's brands per day.

As recommended by Eisenhardt (1989), we created a semi-structured interview script, since we were dealing with qualitative research, based on theoretical references on mapping actions that lead to organizational strategy. The script covers three main themes: the company's position in the shoe GVC, capability development, and path dependence.

We interviewed three managers involved in the company's international activities to provide internal sources of information and insight - the owner (Int1), the finance manager (Int2) and a technical development manager (Int3), all of whom have long-term experience working at this company (from 23 to 40 years). We recorded and transcribed these three interviews, which together totaled two hours and forty-two minutes of recording. This in turn resulted in 51 pages of transcription. We were also granted access to ShoeBR's historical documents, providing secondary evidence. We then supplemented these data from the field with information provided by the Brazilian footwear manufacturer's industry association (www.abicalcados.com.br, retrieved July 12, 2015) and the Brazilian ministry for development, industry and foreign trade - Ministério do Desenvolvimento, Indústria e Comércio Exterior (MDIC) (www.mdic.gov.br, retrieved July 13, 2015).

Since a contingent event can refer to a reaction to environmental changes, we also collected information about the firm's environment. We adapted the interview script to collect additional information about historical events in the shoe industry, mainly in the Brazilian setting. We interviewed three industry experts to provide external sources of information and insight. We chose these people based on their roles and history within the industry. The first of these interviewees (Ext-1) is an executive with great influence in the sector and who has been an opinion former since the period prior to internationalization; the second (Ext-2) joined the technical area when the footwear industry was just starting its international entry process; and the third (Ext-3) has worked for several different companies, each with specific profiles and each of which used different modes of entry. These three interviews resulted in three hours and nine minutes of recording, transcribed into 39 pages of text. Therefore, the corpus on which we based our analysis comprised 90 pages of transcriptions of five hours and fifty-one minutes of interviews.

Once the interviews had been completed, we analyzed, summarized and categorized information before evaluating it in the light both of theory and of secondary information, according to suggestions made by Bardin (1977). We grouped the content of the texts into three categories: position in the shoe GVC, development of capabilities, and path dependence, as mentioned previously.

\section{Describing the Case}

In order to understand the connections between the firm's history and the supply chain's history, before describing the object of the case study in detail, it is necessary to contextualize some historical information about the location in which this shoe manufacturer is established. Therefore, we first briefly trace the historical path followed by the Brazilian shoe industry and then we describe the case. 


\section{Historical information about the Brazilian shoe industry}

The shoe industry has been investigated from the supply chain perspective for a long time. Until World War II, the largest shoe market in the world was the US and its domestic production supplied its own market (Costa \& Passos, 2004; Schmitz, 2006). After World War II, production migrated to European countries (mainly Italy and Spain), taking advantage of the post-war scenario (Costa \& Passos, 2004; Schmitz, 2006). By the end of 1960s, however, low-cost shoe production in Europe was in decline and American private-label owners sought new suppliers in other parts of the world.

An intense confluence of both economic and institutional events brought the already-existing Brazilian production into proximity with international footwear production. Brazilian footwear production was traditionally conducted by family-run businesses (Paiva \& Vieira, 2011) that were part of a shoe-making cluster that had already been manufacturing shoes for decades (Rabellotti \& Schmitz, 1999). At the beginning of the 1970s, Brazilian shoe producers entered the global shoe supply chain and began making shoes for American buyers. These American buyers had originally been producers themselves and were therefore able to provide technical assistance to the Brazilian producers, inspecting production and ensuring compliance with their own standards (Paiva \& Vieira, 2011). This pattern continued for almost two decades, until China began to compete aggressively in the low-cost shoe production sector (Costa \& Passos, 2004; Paiva \& Vieira, 2011; Schmitz, 2006). During the 1990s and early 2000s, extreme institutional and economic changes in Brazil forced the majority of the factories that used to make low-cost shoes to close or to upgrade their manufacturing to produce higher-priced shoes (Paiva \& Vieira, 2011; Vasconcellos, Garrido, Calixto, \& Monticelli, 2013). Most of the agents that used to represent American buyers closed or moved to China (Paiva \& Vieira, 2011). The change in geographical location that took place in the footwear industry is illustrative of one of the principal characteristics of GVCs. As certain resources lose their attractiveness in a given part of the world, the entire GVC is mobilized in search of more attractive locations, in an attempt to maintain its competitive advantages.

Briefly, over these decades, certain critical junctures molded the Brazilian shoe industry after it became involved in GVCs. First, the American buyers arrived (1970). Second, China became a major global shoe producer (1980s). Third, Brazilian currency reform took place, with an extreme revaluation of the Brazilian currency and adoption of the Real (1994). Fourth, economic and social changes took place in Brazil, resulting in higher wages and growth of the domestic market (2000s). Fifth, most of the traders that had represented US buyers moved from Brazil to China (second half of 2000s).

\section{The case of ShoeBR}

We performed this case study at a shoe manufacturer that has 6 manufacturing units (hereafter ShoeBR, a fictitious name). ShoeBR was established in 1948, almost twenty years before US retailers started buying from Brazil. In 2012, the firm was producing 10,000 pairs of women's leather shoes per day. About 300 families are involved as a collective outsourcing, producing woven stripe uppers as well as stitched small pieces embedded in the production. This mode of organization represents a unique resource to ShoeBR production that cannot be imitated by competitors. Besides, it drives ShoeBR to produce their shoes at the same origin the company started in 1948. According to Int1, in 1970, 1 year before it first exported to the US market, ShoeBR was making 1,500 pairs of women's shoes per day, mostly using a moccasin construction technique, with the soles stitched to the uppers. All production was aimed at the domestic market, and the firm had a countrywide brand and national distribution channels.

From 1971 to 1978, US brands purchased all of ShoeBR's production, following the pattern that prevailed in the Sinos Valley. In common with the greater part of the Brazilian shoe industry, ShoeBR discontinued all earlier production patterns, meaning that ShoeBR severed its connections with the domestic market and the American importers imposed their designs through their agents. ShoeBR decided that no marketing was necessary because, as Int1 put it, "we didn't sell; we were bought". 
In 1978, a Dutch shoe seller contacted ShoeBR to make purchases for Europe. Managers saw this relational proximity as an opportunity to enter the European market and to avoid dependence not only on US buyers, but also on their agents (according to both Int2 and Int3). This Dutch agent began to sell moccasin shoes via European catalogs.

According to the files to which we were granted access, by the end of the 1980 s, 60 percent of the production was shipped to Europe, 10 percent was shipped the US, 30 percent was shipped to other regions, and domestic sales were insignificant. In 2011, ShoeBR was exporting its products under its clients' private labels to 53 different countries.

According to Int 1, at the beginning of the 1990s, managers were becoming worried about their dependence on buyers. Since ShoeBR was still located in the Sinos Valley region, which has German heritage, it continued to make moccasin-style women's shoes and managers decided to prioritize production of shoes designed in-house by ShoeBR itself. Int3 pointed out that ShoeBR invested in technology at this point, mainly in design software and production equipment. Interviews with Ext1 revealed that ShoeBR's workers and the local population in general, who were mostly of German heritage, retained some of the leatherworking skills inherited from immigrants who arrived in the region during the nineteenth century.

Int 3 considered the fact that the Europeans began to buy these kinds of shoes mixed in with their own collections was a significant development. As the moccasin style gained acceptance, ShoeBR began to look for clients who did not impose styles. Since it no longer had marketing capabilities and had not developed a global brand, it still needed foreign brands and, more specifically, brands that could pay at least US\$24 per pair.

During the first decade of 2000, wage costs increased and it became harder to find labor (Int1). The changes in economic and social scenarios mentioned above contributed to this process. We asked why ShoeBR did not set up a plant in the Northeast of Brazil (where low-cost labor is available) as other factories had done. Int 1 replied that the type of shoes they make would have been difficult to transfer to the Northeast. There is a specific set of capabilities that are transferred from generation to generation in the region where ShoeBR is located and which is difficult to replicate in other regions. This is both a benefit and a threat. On one hand it offers protection from competitors from Asia, but on the other hand it is a vulnerability to changes that are happening in the social context (Int1).

In 2009, ShoeBR started selling on the domestic market again but not with its own brand. A famous Brazilian brand started to source part of its production from ShoeBR, adopting the same system as the European retailers: ShoeBR still designed its own collection, but did not sell directly to retailers. All three interviewees reported that ShoeBR's lack of branding and marketing capabilities as weaknesses.

The main events in the GVC and the company's responses in terms of strategies and capabilities are illustrated in the timeline as shown in Figure 3. The timeline analysis is discussed in the next section. The timeline highlights 5 junctures that affected the ShoeBR trajectory. The ups and downs in the timeline refer to organizational capabilities transferred or recovered to or from the GVC. 


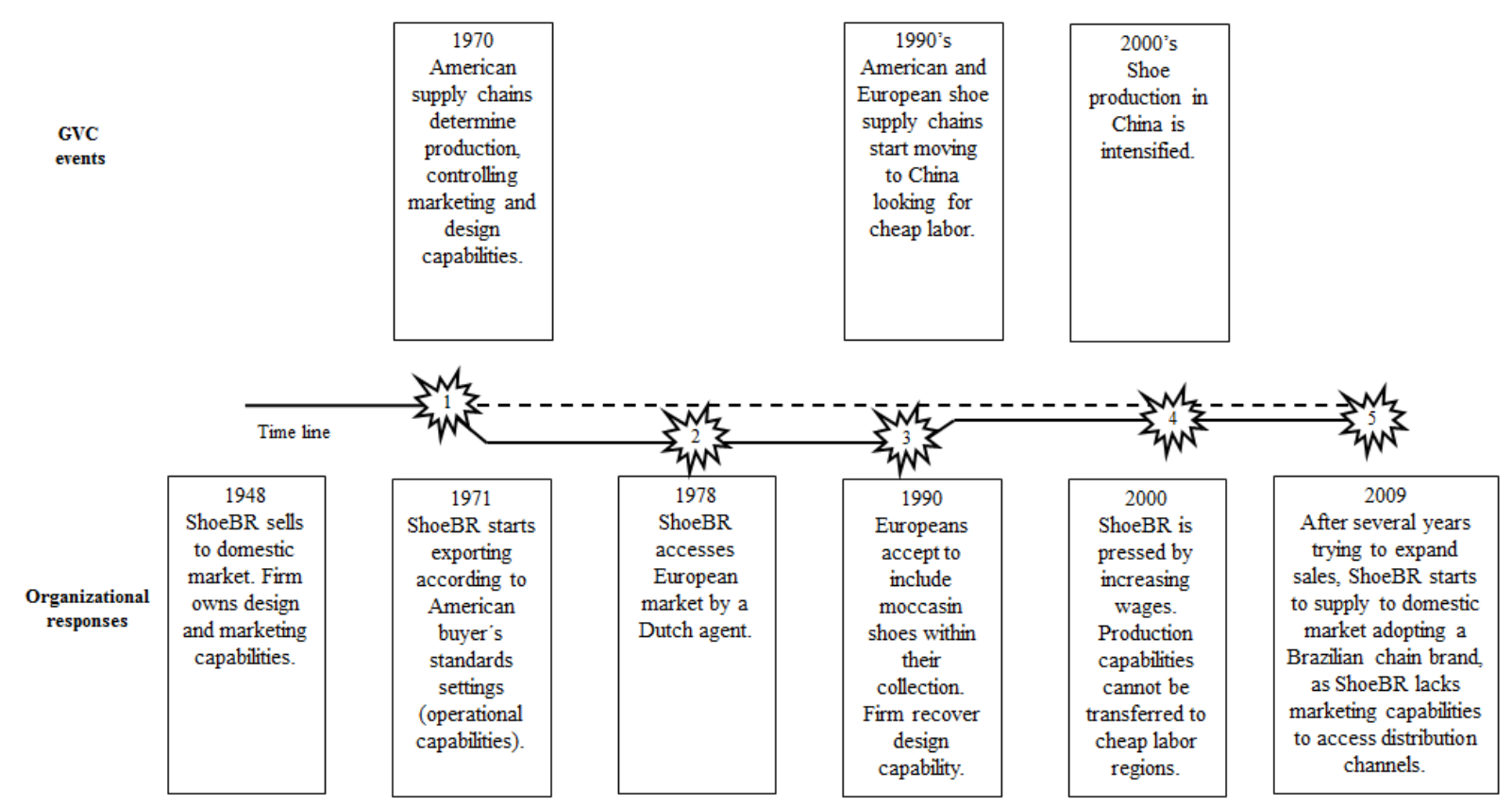

Figure 3. Path Dependence Evidences on ShoeBR Trajectory

\section{Discussion}

Over time, external factors related to the dynamics of shoe industry GVCs led to changes to the firm's strategies and to its modes of participation in supply chains. Initially, the firm began supplying shoes for the US market in the 1970s (juncture 1 in Figure 3). According to the interviewees, the switch from shoe production in Europe to production in emerging countries like Brazil during the 1970s offered the opportunity to enter the international shoe production market. At that time, the firm was a supplier in a global supply chain controlled by a buyer-driven logic (Gereffi, 1994). This experience meant that the firm became able to meet the standards established by global buyers and to focus mainly in manufacturing strategy with competitive priorities such as price and mass scale production (Hayes \& Wheelwright, 1984). Sales did not involve an active strategy. The firm merely produced orders in conformity with orders by US retailers, who bought their production in batches of shoes branded with their own brands which they then resold through their retail networks.

Next, drawing on contacts established with the European market, the firm took advantage of an opportunity to access a higher-priced value chain (juncture 2 in Figure 3). During the 1980s, working mainly for the European market, ShoeBR obtained access to a market segment that it had been unable to reach in the US market. Other relevant events include the consolidation of the European Union and the creation of the Euro. These events allowed ShoeBR to export to countries in Europe, such as the Netherlands, Germany, and England. Although ShoeBR did not improve its position in its existing supply chain, it was able to achieve a better position in a different value chain, in Europe, through relationship management (Borges \& Vieira, 2015) (juncture 3 in Figure 3). This also corroborates Gereffi et al. (2005), who highlighted relational issues to explain how governance in supply chains works. During the 1990's, most of Brazilian shoe exporters moved to cheap labor regions (Brazilian Northeast mostly). Even confronting an intense competition of Chinese production, ShoeBR decide to not transfer its production abroad or to cheaper regions in Brazil (juncture 4 in Figure 3), as ShoeBR's workers and the local population in general retained some of the leatherworking skills inherited from German immigrants who arrived in the region two centuries ago. It would be hardly replicated in other regions, according to interviewees. 
Having realized that the firm was once more in a captive relationship within a supply chain and had little decision-making power, ShoeBR decided to supply shoes designed in-house, choosing styles that were the most appropriate for the production techniques in its region of origin. In 2009, ShoeBR started producing shoes to a Brazilian brand, including their own styles, and replicating the business model established with Europeans retailers previously (juncture 5 in Figure 3). However, even though it now designed its own products, the firm was still captive because of a lack of marketing capabilities. The difficulties to get access to distribution channels abroad and no branding were examples of some problems. Furthermore, while the kind of products that the firm now produced was higher priced than Chinese shoes, the firm was still dependent on specific features of the labor from its region. This finding in particular illustrates how hard it is to move out of captive supply chains, confirming statements made by Gereffi et al. (2005). A supplier needs many capabilities to move up into higher-added value chains, not just related to technical aspects, but also to the capabilities needed to make decisions properly (Paiva \& Vieira, 2011). In the case studied here, it was the capabilities related to marketing and distribution decisions that were lacking. The case study suggests that while it was in the captive relationships with US and European buyers, the firm could upgrade technically, but there was no marketing information available or any transfer of marketing capabilities to support decision-making in this particular valuechain activity. This highlights that only operational capabilities were not enough to move to a higher value chain. The company was locked in the same kind of GVC as before. The captive GVC governance means that company only gets technical information to develop operational capabilities, but does not learn about styles trends, branding and commercialization of the shoes, among others.

Finally, over more recent years, economic and social changes have influenced organizational strategies. As some of the other shoe factories closed, people looked for other kinds of jobs. Additionally, educational improvements in the region developed individual' capabilities to the extent that they were equipped to perform more skilled jobs than manufacturing or shoe production. As a result, labor became scarce and expensive, which forced managers to look for purchasers who could pay higher prices.

This sequence of events illustrates path-dependent decisions. Decisions made in the past, such as the decision to produce for a global buyer's own brand, destroyed marketing capabilities and also led to a decline in production for private labels. Over the history of ShoeBR, many events marked critical junctures, as described by Mahoney (2000). Some of these were related to organizational capabilities (abdication of marketing involvement, technological structure, and labor, this last both in terms of special moccasin production skills and of the increasing labor costs over the last decade).

Other events are related to the supply chain. World economic changes and institutional changes in several countries such as Brazil and China, as well as access to resources have reconfigured the trajectory of this GVC and the advantages linked to certain locations. Scholars agree that changes in the institutional environment affect governance in GVCs (Claessens \& Yurtoglu, 2013; Paiva \& Vieira, 2011; Young et al., 2008). Furthermore, the path dependence perspective can explain some of these changes or why other changes did not happen. Both the organizational history and the GVC history are replete with path dependencies that reinforce decisions made in the past (for instance, giving up on ShoeBR's own brand and abandoning its marketing capabilities). From a relational perspective, a mix of path dependencies are reflected in the history of ShoeBR, usually leading to lock-ins, but also involved in accelerating processes (for example, when the Dutch agent included moccasin shoes in European catalogues, influencing the later decision to start designing all collections in-house at ShoeBR). In summary, the firm exhibited a strategy of reacting to external events, without planning production or marketing strategies over the long term. 


\section{Final Considerations}

When we began this research, we intended to explore a specific variable that plays a role in the supply chain dynamic, which was the capabilities in the supply-base - an intra-firm variable proposed by Gereffi et al. (2005). More specifically, we described it from an organizational perspective, giving consideration to path dependencies that might have influenced strategic decisions. As such, this paper contributes to expanding the GVC framework that has focused on the institutional environment and on inter-firm relationships (Bair, 2009; Gereffi et al., 2005; Gereffi \& Lee, 2012; Paiva \& Vieira, 2011).

After presenting an overview of the GVC perspective and outlining aspects of path dependence at the organizational level, we presented a case study of a firm in the Brazilian shoe industry. This case was selected because it reflects actions that parallel the history of the industry. Some of these actions were reactions to industrial developments. At other times the actions were reactions to organizational limitations. However, all of these actions reflected dependence on the path followed previously.

Gereffi et al. (2005) assumed that supplier capabilities are one of the most relevant factors in upgrading within a supply chain, and we confirmed this in our study. We also confirmed their claim that path dependence should be taken into consideration. Our contribution was to evaluate these assumptions at an organizational level, considering both organizational history and GVC context. The type of GVC governance and capability of the supplier to acquire and perform more added value chain activities is determined both by organizational capabilities as well as its path/trajectory. External events, that the company cannot control, influence its decisions and outcomes. Even that supply chain literature shows a relation between operational capabilities and performance (Klark \& Henderson, 1990), this case study does not confirm it. It can be related to the consumer goods sector (shoes) or to the power of global buyers in this specific chain. Based on the framework of this paper (Figure 2), it is possible to say that although the company decided to move to a higher added value chain, it could not make it for the lack of marketing capabilities to achieve this aim. Answering the research questions, the company was locked in the captive chain governance that did not allowed the development of new capabilities beyond the operational ones. The company has a reactive strategy triggered by changes in the GVC that it was included. However, these changes of strategy regarding the development of capabilities did not succeed in taking it to a higher added value chain or to a position of more bargain power. The findings also confirm Paiva and Vieira (2011) that the level of the control of value chain activities such as marketing are determinant for a higher value added chain.

Our main limitation is inherent to the single case study method we chose, even when such studies are in-depth, as here where we analyzed documents and interviewed three people with a long history in the firm and also interviewed three experts from the industry. Further limitations are the fact that we covered just one industry in just one country (Brazil).

As a possible avenue for the research agenda, we suggest exploring path dependence in longitudinal studies. Evidence on this subject has been increasing in several different areas of knowledge because it helps to understand why managers sometimes make decisions in a different manner than that which would appear the most logical option. We also suggest comparing different firms within a specific GVC, observing their decisions and how they try to upgrade their positions through the development of capabilities. Future research could also test whether companies that are located in different countries, but which are members of the same GVC, take different decisions based on their cultural and institutional backgrounds. The framework could be tested to identify companies that broke the determinism of the GVC and developed capabilities to move to higher added value chains. Another aspect to be explored in future research is the possible de-internationalization that can occur if an organization does not develop the marketing and branding capabilities needed to compete globally. 


\section{References}

Arthur, W. B. (1989). Competing technologies, increasing returns, and lock-in by historical events. The Economic Journal, 99(394), 116-131. doi: 10.2307/2234208

Bair, J. (2009). Frontiers of commodity chain research. California: Stanford University Press.

Bardin, L. (1977). Análise de conteúdo. Lisboa: Edições 70.

Barney, J. (1991). Firm resources and sustained competitive advantage. Journal of Management, 17(1), 99-120. doi: 10.1177/014920639101700108

Barney, J. (1995). Looking inside for competitive advantage. Academy of Management Executive, 9(4), 49-61.

Booth, C. (2003). Does history matter in strategy? The possibilities and problems of counterfactual analysis. Management Decision, 41(1), 96-104. doi:10.1108/00251740310445545

Borges, M. A., \& Vieira, L. (2015). Global supply chain capabilities: a framework proposal. In J. Stentoff, A. Paulraj, \& G. Vastag (Eds.), Research in the decision sciences for innovations in global supply chain networks (pp. 27-46). Upper Saddle River, NJ: Pearson Education - Financial Times Press.

Choi, T. Y., \& Krause, D. R. (2006). The supply base and its complexity: implications for transaction costs, risks, responsiveness, and innovation. Journal of Operations Management, 24(5), 637-652. doi: 10.1016/j.jom.2005.07.002

Claessens, S., \& Yurtoglu, B. B. (2013). Corporate governance in emerging markets: a survey. Emerging Markets Review, 15, 1-33.

Costa, A. B., \& Passos, M. A. (2004). A indústria calçadista no Rio Grande do Sul. São Leopoldo: UNISINOS.

David, P. A. (1985). CLIO and the economics of QWERTY. Economic History, 75(2), 332-337.

Eisenhardt, K. M. (1989). Building theories from case study research. Academy of Management Review, 14(4), 532-550. doi: 10.5465/AMR.1989.4308385

Feenstra, R. (1998). Integration of trade and disintegration of production in the global economy. The Journal of Economic Perspectives, 12(4), 31-50. doi: 10.1257/jep.12.4.31

Galvin, P., \& Morkel, A. (2001). The effect of product modularity on industry structure: the case of the world bicycle industry. Industry and Innovation, 8(1), 31-47.

Gereffi, G. (1989). Rethinking development theory: insights from East Asia and Latin America. Sociological Forum, 4(4), 505-533. doi: 10.1007/BF01115062

Gereffi, G. (1994). The organization of buyer-driven global commodity chains: how US retailers shape overseas production networks. In G. Gereffi \& M. Korzeniewicz (Eds.), Contributions in economics and economic history (pp. 95-122). Westport, CT: Praeger.

Gereffi, G. (1999). International trade and industrial upgrading in the apparel commodity chain. Journal of International Economics, 48(1), 37-70. doi:10.1016/S0022-1996(98)00075-0

Gereffi, G., Humphrey, J., \& Sturgeon, T. (2005). The governance of global value chains. Review of International Political Economy, 12(1), 78-104. doi:10.1080/09692290500049805 
Gereffi, G., \& Korzeniewicz, M. (1989). Commodity chains and footwear exports in the semiperiphery [N.81]. Duke University Program in Political Economy, Durham, NC, USA.

Gereffi, G., \& Lee, J. (2012). Why the world suddenly cares about global supply chains. Journal of Supply Chain Management, 48(3), 24-32. doi:10.1111/j.1745-493X.2012.03271.x

Grant, R. M. (1991). The resource-based theory of competitive advantage: implications for strategy formulation. California Management Review, 33(3), 114-135.

Håkansson, H., \& Ford, D. (2002). How should companies interact in business networks? Journal of Business Research, 55(2), 133-139. doi:10.1016/S0148-2963(00)00148-X

Hayes, R. H., \& Wheelwright, S. C. (1984). Restoring our competitive edge: competing through manufacturing. New York, NY: John Wiley \& Sons.

Holweg, M., \& Pil, F. (2008). Theoretical perspectives on the coordination of supply chains. Journal of Operations Management, 26(3), 389-406. doi:10.1016/j.jom.2007.08.003

Jarillo, J. C. (1993). Strategic networks: creating the borderless organization. Oxford: ButterworthHeinemann.

Jarzabkowski, P. (2002). Strategy as practice: recursiveness, adaptation and strategic practices-in-use. Strategy, (0121), 0-35.

Kaplinsky, R., \& Morris, M. (2001). A handbook for value chain research. Brighton: University of Sussex Institute for Development Studies.

Kim, W. S. (2006). The effect of supply chain integration on the alignment between corporate competitive capability and supply chain operational capability. International Journal of Operations \& Production Management, 26(10), 1084-1107. doi:10.1108/01443570610691085

Klark, K. B., \& Henderson, R. M. (1990). Architectural innovation: the reconfiguration of existing product technology and the failure of established firms. Administrative Science Quarterly, 35(1), 9-30.

Mahoney, J. (2000). Path dependence in historical sociology. Theory and Society, 29(4), 507-548.

Morash, E. A. (2000). Supply chain strategies, capabilities, and performance. Transportation Journal, $41(1), 38-54$.

Navas-Alemán, L. (2011). The impact of operating in multiple value chains for upgrading: the case of the brazilian furniture and footwear industries. World Development, 39(8), 1386-1397. doi: 10.1016/j.worlddev.2010.12.016

Nelson, R. R., \& Winter, S. G. (1982). An evolutionary theory of economic change. Cambridge: Harvard University Press.

Paiva, E., \& Vieira, L. (2011). Strategic choices and operations strategy: a multiple cases study. International Journal of Services and Operations, 10(2), 119-135. Retrieved from http://inderscience.metapress.com/index/N23288W82P312273.pdf. 10.1504/IJSOM.2011.042514

Patel, P., \& Pavitt, K. (1997). The technological competencies of the world's largest firms: complex and path-dependent, but not much variety. Research Policy, 26(2), 141-156. doi: 10.1016/S00487333(97)00005-X

Peng, M. W. (2002). Towards an institution-based view of business strategy. Asia Pacific Journal of Management, 19(2), 251-267. doi: 10.1023/A:1016291702714 
Penrose, E. T. (1959). The theory of the growth of the firm. New York: Wiley.

Prahalad, C. K., \& Hamel, G. (1990). The core competence of the corporation. Harvard Business Review, 68(3), 79-91.

Rabellotti, R., \& Schmitz, H. (1999). The internal heterogeneity of industrial districts in Italy, Brazil and Mexico. Regional Studies, 33(2), 97-108. doi: 10.1080/00343409950122909

Schmitz, H. (2006). Learning and earning in global garment and footwear chains. The European Journal of Development Research, 18(4), 546-571. doi: 10.1080/09578810601070688

Schmitz, H., \& Knorringa, P. (2000). Learning from global buyers. The Journal of Development Studies, 37(2), 177-205. doi: 10.1080/713600073

Sydow, J., Schreyögg, G., \& Koch, J. (2009). Organizational path dependence: opening the black box. Academy of Management Review, 34(4), 689-709. Retrieved from http://amr.aom.org/content/34/4/689.short

Teece, D. J., Pisano, G., \& Shuen, A. (1997). Dynamic capabilities and strategic management. Strategic Management Journal, 18(7), 509-533. doi: 10.1002/(SICI)1097-0266(199708)18:7<509::AIDSMJ882>3.0.CO;2-Z

Ulrich, D., \& Lake, D. G. (1990). Organizational capability. New York: John Wiley \& Sons.

Vasconcellos, S. L., Calixto, C. V., Garrido, I. L., \& Souza, Y. S. de (2012). A dependência de trajetória em negócios internacionais. BASE - Revista de Administração e Contabilidade da Unisinos, 9(3), 306-315. doi: 10.4013/base.2012.93.08

Vasconcellos, S. L., Garrido, I. L., Calixto, C. V., \& Monticelli, J. M. (2013, July). Historical anchors over resources in international strategy. Proceedings of AIB 2013 Annual Meeting, Istanbul, Turkey.

Williamson, O. (1975). Markets and hierarchies, analysis and antitrust implications: a study in the economics of internal organization. Glencoe: Free Press.

Williamson, O. E. (1992). Markets, hierarchies , corporation: an unfolding perspective and the modern. Journal of Economic Behavior and Organization, 17(2), 335-352.

Young, M. N., Peng, M. W., Ahlstrom, D., Bruton, G. D., \& Jiang, Y. (2008). Corporate governance in emerging economies: a review of the principal-principal perspective. Journal of Management Studies, 45(1), 196-220. doi: 10.1111/j.1467-6486.2007.00752.x

\section{Authors' Profiles}

Silvio Luis de Vasconcellos

Av. Unisinos, 950, 93022-000, São Leopoldo, RS, Brazil. E-mail address: silviolvasconcellos@ gmail.com

Ivan Lapuente Garrido

Av. Unisinos, 950, 93022-000, São Leopoldo, RS, Brazil. E-mail address: igarrido@unisinos.br

Luciana Marques Vieira

Av. Unisinos, 950, 93022-000, São Leopoldo, RS, Brazil. E-mail address: lmvieira@ unisinos.br

Luis Carlos Schneider

Av. Unisinos, 950, 93022-000, São Leopoldo, RS, Brazil. E-mail address: luiscschneider@ gmail.com 